\title{
In Vivo Release of Testosterone from Hydrophobic-Hydrophilic Copolymer Composites in Long Term Delivery Systems
}

\author{
Masaru YoshidA, Masaharu AsANo, Isao KAETSU, \\ Katsuyuki NaKaI, ${ }^{*}$ Hidetoshi YamanaKa, ${ }^{*}$ Keizo SHIDA, ${ }^{*}$ \\ and Keiji SUZUKI** \\ Takasaki Radiation Chemistry Research Establishment, \\ Japan Atomic Energy Research Institute, Takasaki, Gunma 370-12, Japan \\ * Department of Urology, School of Medicine, \\ Gunma University, Maebashi, Gunma 371, Japan \\ **Department of Pathology, College of Medical Care and Technology, \\ Gunma University, Maebashi, Gunma 371, Japan
}

(Received April 8, 1982)

\begin{abstract}
The in vitro release of testosterone from hydrophobic-hydrophilic copolymerdrug composites in cylindrical form produced by radiation was investigated over a period of 400 days. The release rates could be controlled in the range of approximately 10 to $200 \mu \mathrm{g} / \mathrm{day}$ by changing the monomer composition and kept constantly during the tests. The in vivo release was studied by implanting the composite into rats for a maximum period of 90 days. The results of in vitro and in vivo release of testosterone showed that the in vitro cumulative amount of released drug agreed with that of the in vivo test. The surface of implanted homopolymer carrier was covered by tissue cells and the in vivo released rate was retarded. However, no cell adhesion was observed on the copolymer carrier surface used in this study. Mechanical strength and biocompatibility of copolymers were also evaluated by tensile strength test and microscopic observation, respectively.

KEY WORDS Hydrophobic-Hydrophilic Copolymer / Testosterone / Drug

Delivery System / Radiation-Induced Polymerization / In Vivo Release /

Castrated Rat / Biocompatibility / Implantation /
\end{abstract}

The development of implantable systems for sustained release of drugs at a controlled rate has been studied by many workers since Saunder and Raymond discovered that the release desiccated hormone from waxy pellets can be carried out at a slow and durable rate. ${ }^{1-9}$ Using various synthetic polymers, the sustained delivery of drugs has also been investigated, e.g., the copolymer of methacrylate-methyl methacrylate, ${ }^{10}$ the copolymer of ethylene and vinyl acetate, ${ }^{11}$ hydrogels, ${ }^{12-14}$ and polysiloxanes. ${ }^{15-17}$ These synthetic polymers are good for long term release and have good mechanical properties, though they undergo degradation to a small extent in vivo.

We studied the entrapment of bioactive agents such as enzymes, microbial cells, and organelles in vinyl polymer matrices by means of radiationinduced polymerization of various monomers ${ }^{18-22}$ and reported the migration of a drug through solid polymer composites of various shapes. ${ }^{23-25}$ The vinyl polymer-anticancer drug composites made by the above procedure were applied successfully to local chemotherapy in clinical tests. ${ }^{26}$ )

In the case of homopolymer systems, the in vivo release rates of drugs were considerably faster than in vivo. ${ }^{27}$ The retardation of the in vivo release increased with the water content of the carrier polymer. However, no difference between in vitro and in vivo release was observed when hydrophobic-hydrophilic copolymers were used as carriers for the drug delivery system. In this paper, we report the correlation between the two releasing systems of testosterone from drug-copolymer composites in cylindrical form. The composites consisting of testosterone and the copolymers of hydrophobic diethylene glycol dimethacrylate and hydrophilic carriers were prepared by means of radiation-induced copolymerization at low tem- 
perature. Poly(ethylene glycol) \#600 dimethacrylate, 2-hydroxyethyl methacrylate, $N$-vinyl-2-pyrrolidone, and $\omega$-methoxypoly(ethylene glycol) $\# 400$ methacrylate were used as hydrophilic carriers.

\section{EXPERIMENTAL}

\section{Materials}

A hydrophobic carrier monomer such as diethylene glycol dimethacrylate $(2 \mathrm{G})$ and a hydrophilic carrier monomer such as polyethylene glycol \#600 dimethacrylate (14G), 2-hydroxyethyl methacrylate (HEMA), $N$-vinyl-2-pyrrolidone (NVP), and $\omega$-methoxypoly(ethylene glycol) \#400 methacrylate (M9G) were obtained from Shin-Nakamura Chemical Co., Ltd. These monomers were purified by washing with $1 \% \mathrm{NaOH}$, passing over Amberlist A-27 (Rohm \& Haas), drying over molecular sieves $4 \mathrm{~A}$, and distillation according to conventional methods.

Testosterone obtained from Fluka AG was used as a drug and ground to a powder less than $20 \mu \mathrm{m}$.

\section{Preparation of Copolymer-Drug Composites}

Hydrophobic $2 \mathrm{G}$ carrier and other hydrophilic carriers such as 14G, HEMA, NVP, and M9G were mixed to the required composition. The carrier mixture $(0.2 \mathrm{ml})$ was charged into a $8 \mathrm{~mm}$ diameter flat-bottom-type glass ampoule and testosterone $(100 \mathrm{mg})$ was added to the carrier mixture. The ampoule was sealed off under a vacuum of $10^{-3}$ $\mathrm{mmHg}$. The sealed ampoule was vigorously shaken at room temperature and then cooled rapidly to a temperature of $-78^{\circ} \mathrm{C}$ (with a Dewar vessel kept at $-78^{\circ} \mathrm{C}$ in dry ice-methanol system), to obtain the homogenic carrier-drug suspension mixture in a supercooled state. The irradiation was carried out using a ${ }^{60} \mathrm{Co}$ source at $-78^{\circ} \mathrm{C}$ for 2 hours at a dose rate of $0.5 \mathrm{Mrad} \mathrm{h}^{-1}$. After irradiation, the copolymer-drug composites obtained in this study were very hard, $8 \mathrm{~mm}$ in diameter and $4 \mathrm{~mm}$ long in cylindrical form.

From the results of spectroscopic analysis, it was found that the absorbance at $249 \mathrm{~nm}$ of irradiated testosterone $\left(1 \mathrm{Mrad}\right.$ at $-78^{\circ} \mathrm{C}$, in vacuo $)$ agreed with that of an unirradiated sample. Therefore, it may be concluded that testosterone is hardly denatured under the irradiation conditions described above. The monomers used in this study were quickly polymerized under such conditions and reached $100 \%$ polymer conversion. In this case, the polymer conversion was measured by isolating with ethanol, drying, and weighing the polymer. It was also found that the recovery of testosterone from copolymer-drug composites was higher than $96 \%$ in all composite systems.

\section{Tensile Test of Pure Copolymers}

Pure hydrophobic-hydrophilic copolymer membranes (containing no drug) were made by means of casting polymerization under the following irradiation conditions: $1 \mathrm{Mrad}$ at $-78^{\circ} \mathrm{C}$, in nitrogen. The size of the membrane was $0.1 \mathrm{~mm}$ in thickness, $100 \mathrm{~mm}$ wide, and $40 \mathrm{~mm}$ long. The membrane in the polymerized state was immersed in a $0.1 \mathrm{M}$ phosphate buffer solution ( $\mathrm{pH} 7.4$ ), for 90 days at $37^{\circ} \mathrm{C}$ and then tested. A tensile test (10 samples/ group) was carried out at a crosshead speed of $5 \mathrm{~cm}$ $\min ^{-1}$ at $25^{\circ} \mathrm{C}$ with an Instron tensile test machine, Model 1130 (Instron Corp).

\section{Water Content of Pure Copolymers}

The water content of pure copolymers $(W)$ was determined by,

$$
W(\%)=\frac{W_{\mathrm{w}}}{\left(W_{\mathrm{p}}+W_{\mathrm{w}}\right)} \times 100
$$

where $W_{\mathrm{w}}$ and $W_{\mathrm{p}}$ are the weight of the water required to saturate the copolymer and that of the dried copolymer, respectively.

\section{In Vitro Test System}

The in vitro release rate of testosterone from a hydrophobic-hydrophilic copolymer composite in cyclindrical form was determined in the following way. The test was carried out at $37^{\circ} \mathrm{C}$ with a shaking incubator, Model TA-16T, Takasaki Kagaku Kikai Co., Ltd. A composite (10 samples/group) was placed in the flask containing $100 \mathrm{ml}$ of $0.1 \mathrm{M}$ phosphate buffer solution ( $\mathrm{pH}$ 7.4) as an elution medium. The flask was shaken at a rate of 100 times a minute. At appropriate time intervals, the testosterone concentration in the medium was measured spectrophotometrically at $249 \mathrm{~nm}$ with a Shimadzu double beam spectrophotometer, Model UV-200. The elution medium was exchanged with fresh medium in each assay. In some cases, the composite was collected from the eluted medium and the cumulative amounts of testosterone released during the 30,60 , and 90 day test periods were estimated 
from the amount of drug left in the composite.

On the other hand, pure copolymer matrices $(0.5 \mathrm{~g})$ were immersed in a flask with $30 \mathrm{ml}$ of $0.1 \mathrm{M}$ phosphate buffer solution ( $\mathrm{pH} 7.4)$ and treated for 300 days at $37^{\circ} \mathrm{C}$. The substances dissolved in the medium from the matrices were analyzed with a gas chromatography. The absorption owing to the remained monomer could not be observed. At the same time, the change in the weight of pure copolymer matrices after the dissolution test was also measured. The decrease in the weight of the copolymers was less than $0.06 \%$ for all copolymer systems. Accordingly, it was concluded that the substances dissolved in vitro from the copolymer itself were negligible.

\section{In Vivo Test System}

Wistar rats (3 rats/group), weighing approximately $300-400 \mathrm{~g}$, were used in this study. All the rats were castrated via the scrotal route under ether anesthesia. A copolymer-drug composite was washed with ethanol for sterilization and then implanted subcutaneously in the back of a rat on the 14th day after castration. At fixed intervals of time, the composites were collected from the sacrificed animals and the in vivo cumulative amount of testosterone released at $30 \mathrm{th}, 60 \mathrm{th}$, and 90 th day from implantation was estimated from the amount of drug left in the composite.

The efficacy of testosterone released from those composites was determined by the physiological response in rats, e.g., weight of ventral prostate or serum testosterone concentration. The ventral prostate was removed and weighed. The serum testosterone concentration was measured by radioimmunoassay according to the method of Makino. ${ }^{28}$ Here, the units for the weight of the ventral prostate per $100 \mathrm{~g}$ of body weight (rat) and for the amount of testosterone found in serum are expressed by the $\mathrm{mg} / 100 \mathrm{gbw}$ and $\mathrm{ng} \mathrm{ml}^{-1}$, respectively.

The apparent total proteins (tissue cells) adherent to the surface of a pure copolymer matrix after 30 days implantation (3 matrices/rat and 3 rats/group) were measured according to Imai's method. ${ }^{29}$ The pure copolymer matrices were washed with distilled water ( $\mathrm{pH} 6.0$ ) and stained with $0.5 \%$ crystal violet for 3 minutes. After being washed for 7 minutes, crystal violet was extracted with $1 \%$ sodium dodecyl sulfate, and the absorbance of the dye was measured spectrophotometrically at $598 \mathrm{~nm}$. As a blank, the same procedure was repeated with unimplanted pure copolymers.

\section{Microscopic Observation}

The pure copolymer matrices (containing no testosterone) were implanted subcutaneously in the backs of the rats. After 30 days implantation, the tissues surrounding the copolymers were preserved in $10 \%$ buffered formalin. All tissues selected for optical microscopic study were embedded in paraffin, then sectioned at about $4 \mu \mathrm{m}$, and stained with hematoxylin and eosin. Photomicrographs were taken using an Olympus, Model FHF microscope with Olympus PM-10-M equipment.

\section{RESULTS AND DISCUSSION}

\section{Tensile Strength of Hydrophobic-Hydrophilic Copolymers}

In the poly(ethylene glycol) dimethacrylate carrier series,

$$
\mathrm{CH}_{2}=\mathrm{C}\left(\mathrm{CH}_{3}\right) \mathrm{COO}\left(\mathrm{CH}_{2} \mathrm{CH}_{2} \mathrm{O}\right)_{n} \mathrm{OC}\left(\mathrm{CH}_{3}\right) \mathrm{C}=\mathrm{CH}_{2} \text {, }
$$

the copolymer membranes of hydrophobic $2 \mathrm{G}(n=$ 2) and hydrophilic $14 \mathrm{G}(n=14)$ were made by means of casting polymerization. Figure 1 shows the relationship between the tensile strength of the membranes and the carrier composition. The tensile strength of copolymer in the polymerized state without further drying was found to give a maximal carrier composition value of $50 / 50(2 \mathrm{G} /$ $14 \mathrm{G})$. When the copolymer was placed in a buffer solution ( $\mathrm{pH} 7.4$ ) for 90 days at $37^{\circ} \mathrm{C}$, the maximal strength shifted to the side of the $2 \mathrm{G}$ rich carrier composition. In the $2 \mathrm{G}$ rich carrier composition range, the swollen copolymer membrane showed a tensile strength higher than that of the copolymer in the polymerized state.

The tensile strength of the copolymer membranes of hydrophobic $2 \mathrm{G}$ and other hydrophilic carriers such as HEMA, NVP, and M9G was also determined in the swollen state. The tensile strength of the copolymers ( $50 \mathrm{vol} \%$ of $2 \mathrm{G}$ ) was found to be 190,170 , and $140 \mathrm{~kg} \mathrm{~cm}^{-2}$, respectively. The water content of these copolymers is listed in Table I. Hosaka and co-workers reported the tensile strength of HEMA polymer membrane at $37 \%$ water content to be $10 \mathrm{~kg} \mathrm{~cm}^{-2}$. Therefore, it is obvious that the tensile strength of the copolymers used in this study is superior to that of the 
HEMA polymer. ${ }^{13)}$

The deterioration of copolymers was investigated by measuring the tensile strength of a copolymer membrane implanted subcutaneously on the back of a rat. In this case, a copolymer of $2 \mathrm{G} / 14 \mathrm{G}(80$ vol $\%$ of $2 \mathrm{G}$ ) was implanted for 90 days. Following this, the tensile strength of the membrane was found to be $194 \mathrm{~kg} \mathrm{~cm}^{-2}$. This value agrees very closely with that of the $2 \mathrm{G} / 14 \mathrm{G}$ ( $80 \mathrm{vol} \%$ of $2 \mathrm{G}$ ) copolymer swollen with water in Figure 1. The change in weight of the copolymer after 90 days implantation was determined gravimetrically. The weight loss was almost negligible. It was thus concluded that the copolymer was but little degraded in vivo.

\section{In Vitro and In Vivo Correlation with Release of Testosterone}

Figure 2 shows the in vitro rate of drug delivery from $2 \mathrm{G} / 14 \mathrm{G}$ copolymer composites. The release test was carried out over a period of 400 days. The daily amount of drug released reached a maximum in the first 3 days, continued to decrease during the next 27 days, and then remained relatively constant. Figure 3 shows the relationship between the in vitro rate of release after $30,60,90,200$, and 400 days and the carrier composition. The rate of drug delivery showed a linear increase in proportion to the increase of the $14 \mathrm{G}$ component in the copolymer. The reason for this may possibly be the increase in the water content of the $2 \mathrm{G} / 14 \mathrm{G}$ copolymers as shown in Figure 3. Figure 3 also shows that the in vitro rate from the $2 \mathrm{G} / 14 \mathrm{G}$ copolymer composites can be controlled in the range of approximately 10 to $220 \mu \mathrm{g} /$ day by changing the carrier composition. That is, the overall rates from 2G/14G copolymer composites having a composition of $100 / 0,80 / 20,50 / 50,20 / 80$, and $0 / 100$ were found to be $10,60,120,160$, and $220 \mu \mathrm{g} / \mathrm{day}$. In this case, the difference in the release rate during the first 30 to 400 days with the test was 2,20 , 40,50 , and $40 \mu \mathrm{g} /$ day in the above order. These results demonstrate the feasibility of controlled delivery of testosterone from copolymer-drug composites over a period of several years.

The in vitro rate of drug delivery from composites containing copolymers $(50 / 50)$ of $2 \mathrm{G}$ and hydrophilic carriers such aa HEMA, M9G, and NVP except for $14 \mathrm{G}$ was also determined and the relationship between the in vitro rate at 30 th day from start of the test and the water content $(w)$ of co-

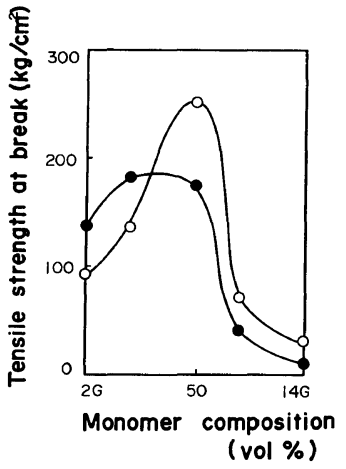

Figure 1. Tensile strength of $2 \mathrm{G} / 14 \mathrm{G}$ copolymer membranes. The copolymer membranes were immersed in a $0.1 \mathrm{M}$ phosphate buffer solution $(\mathrm{pH} 7.4)$ at $37^{\circ} \mathrm{C}$ : (O), before immersion (copolymer in the polymerized state); (O), after 90 days immersion.

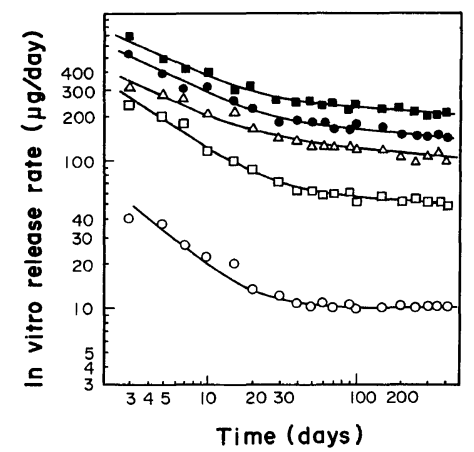

Figure 2. In vitro rate of drug delivery from $2 \mathrm{G} / 14 \mathrm{G}$ copolymer compositions. $2 \mathrm{G} / 14 \mathrm{G}$ carrier composition:

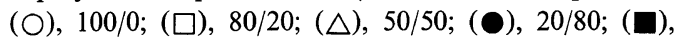
$0 / 100$.

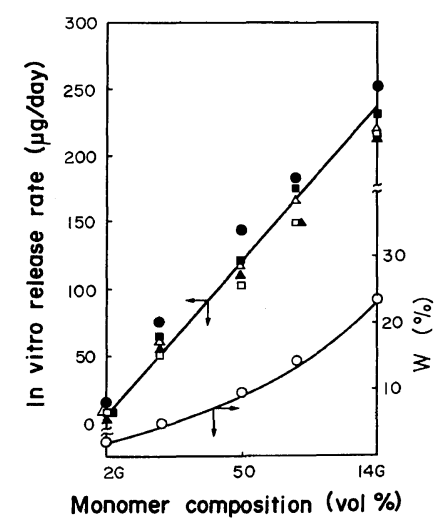

Figure 3. Effects of $2 \mathrm{G} / 14 \mathrm{G}$ carrier composition on the in vitro rate of drug delivery from the composites and on the water content $(W)$ of pure copolymers. Release time (days): $(\bigcirc), 30 ;(\square), 60 ;(\triangle), 90 ;(\Delta), 200 ;(\square)$, 400 . 
Table I. Physiological response in castrated rats with testosterone-containing composites in the $50 / 50$ (hydrophobic $2 \mathrm{G} /$ other hydrophilic carriers)

carrier composition system ${ }^{\mathrm{a}}$

\begin{tabular}{|c|c|c|c|c|c|c|}
\hline \multirow{3}{*}{$\begin{array}{l}\text { Copolymer } \\
\text { system }\end{array}$} & \multirow{3}{*}{$\frac{W}{\%}$} & \multirow{3}{*}{$\begin{array}{c}\begin{array}{c}\text { In vitro } \\
\text { release } \\
\text { rate at } \\
30 \text { th day }\end{array} \\
\mu \mathrm{g} / \mathrm{day}\end{array}$} & \multicolumn{2}{|c|}{ Body weight (g) } & \multirow{3}{*}{$\begin{array}{c}\begin{array}{c}\text { Weight of } \\
\text { ventral } \\
\text { prostate }\end{array} \\
\mathrm{mg} / 100 \mathrm{gbw}\end{array}$} & \multirow{3}{*}{$\begin{array}{c}\begin{array}{c}\text { Serum } \\
\text { testosterone } \\
\text { concentration }\end{array} \\
\mathrm{ng} \mathrm{ml}{ }^{-1}\end{array}$} \\
\hline & & & \multirow{2}{*}{ Start } & \multirow{2}{*}{ Sacrifice } & & \\
\hline & & & & & & \\
\hline $2 \mathrm{G} / 14 \mathrm{G}$ & 9.5 & 140 & 360 & 480 & 72.46 & 3.22 \\
\hline 2G/HEMA & 10.1 & 110 & 340 & 450 & 66.61 & 2.41 \\
\hline $2 \mathrm{G} / \mathrm{M} 9 \mathrm{G}$ & 18.7 & 300 & 350 & 470 & 138.46 & 8.94 \\
\hline $2 \mathrm{G} / \mathrm{NVP}$ & 21.8 & 90 & 370 & 540 & 47.45 & 2.67 \\
\hline None (control) & - & - & 380 & 460 & 8.87 & 0.39 \\
\hline
\end{tabular}

a Implantation period, 30 days.

polymers is shown in Table I. With these copolymer systems, the rate of drug delievery was found not to depend on the water content of copolymers. The relationship between the rate of drug delivery from various copolymer composites such as $2 G$ / HEMA, 2G/M9G, and 2G/NVP and the water content of copolymers was plotted as a function of carrrier composition as was done in the case of the 2G/14G copolymer composite shown in Figure 3 . It was found that the rate of drug delivery increased in all copolymer systems with an increase in the hydrophilic component, i.e., the water content of copolymers. This tendency is consistent with the results obtained with the $2 \mathrm{G} / 14 \mathrm{G}$ copolymer composite. Thus it may be concluded that one of the release-controlling factors is the water content of the copolymers. But it was also found from Table I that water content is not the sole factor governing the release of testosterone. The apparent solubility of testosterone in carriers (monomers) such as 2G/M9G, 2G/14G, 2G/HEMA, and 2G/NVP $\left(50 / 50\right.$, in all systems) was determined at $25^{\circ} \mathrm{C}$. The values of solubility were found to be $20,30,120$, and $210 \mathrm{mg} \mathrm{ml}^{-1}$, in the above order. This shows that the ratio between testosterone dispersed in the molecular state and that in the crystal state is significantly influenced by the kind of carrier. The release rate of testosterone in the molecular state is slower than that in the crystal state.

This may be related to the difference in drug concentration per a unit volume of the composite. That is, the drug concentration per a unit volume of the former composite is lower than that of the latter.

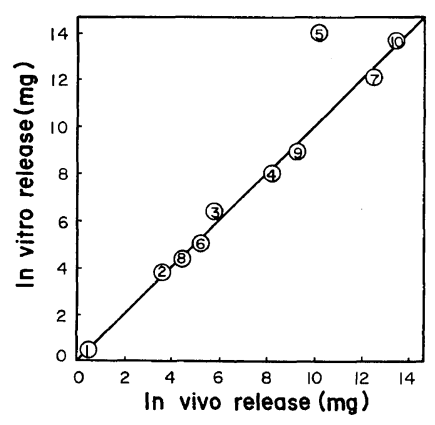

Figure 4. Comparison of the in vitro and in vivo cumulative amounts of drug released from various copolymer composites. Carrier composition: (1), 2G (100); (2), 2G/14G (80/20); (3), 2G/14G (50/50); (4), 2G/14G (20/80); (5), 14G (100); (6), 2G/HEMA (50/50); (7), 2G/M9G (50/50); (8), 2G/NVP (50/50); (9), 2G/14G (80/20); (10), 2G/14G (80/20). Release time: (1)-(8), 30 days; (9), 60 days; (10), 90 days.

Consequently, the rate of drug delivery from various copolymer composites decreases in the order of $2 \mathrm{G} / \mathrm{M} 9 \mathrm{G}>2 \mathrm{G} / 14 \mathrm{G}>2 \mathrm{G} / \mathrm{HEMA}>2 \mathrm{G} / \mathrm{NVP}$ (50/50, in all systems), in proportion to the solubility of the drug.

Figure 4 shows the in vitro and in vivo correlation of the release of testosterone from various copolymer composites. According to Figure 4, the in vivo cumulative amount of drug released during the 30 day test period was in fair agreement with that of in vitro test. Even on the 90th day of the test, the same tendency could be observed from the results between the in vitro and in vivo release in a $2 \mathrm{G} / 14 \mathrm{G}$ (80/20) copolymer composite. 


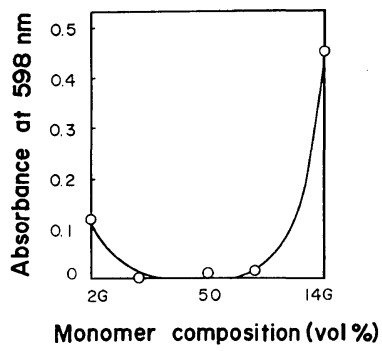

Figure 5. Apparent total protein adhering to the surface of $2 \mathrm{G} / 14 \mathrm{G}$ copolymer matrices after 30 days implantation.

In the $100 \% 14 \mathrm{G}$ polymer composite (sample 5 in Figure 4), the in vitro cumulative amount of drug released during the 30 day test period was considerably higher than in vivo. This difference is usually evident in a nonıupolymer composite system ( $100 \mathrm{vol} \%$ of carrier) made by the radiation-induced polymerization of a glass-forming monomer at low temperature. ${ }^{27}$ That is, the retardation of in vivo release in comparison with the in vitro release occurs remarkably in hydrophilic polymer carriers. This is considered to result from the adhesion and covering of the polymer surface by tissue cells. Cell adhesion occurs more actively with increasing water content of the polymers. The in vivo release of drug is thus retarded by an increase in diffusion resistance owing to the layer cells on the surface of the polymer. In contrast, in the case of the copolymers of hydrophobic $2 \mathrm{G}$ and various hydrophilic carriers such as HEMA, NVP, M9G, and $14 \mathrm{G}$, this difference is almost negligible as evident from Figure 4. The apparent total proteins (tissue cells) adhering to the surface of the copolymer were determined by implanting the copolymer into rats during the 30 day test period. Figure 5 shows the effect of $2 \mathrm{G} / 14 \mathrm{G}$ carrier composition on the apparent total proteins adhering on the surface of the copolymers. In homopolymers such as $2 \mathrm{G}(W=3.9 \%)$ and $14 \mathrm{G}$ $(W=44.8 \%)$, the absorbance at $598 \mathrm{~nm}$ as a measure of the apparent total proteins was 0.12 and 0.45 , respectively. In this case, the apparent total proteins showed a further tendency to increase with long period of implantation. However, there was no adhesion of proteins (cells) on the surface of the copolymer by implantation as can be seen from Figure 5. This was also confirmed by microscopic observation of the surface of copolymer. ${ }^{27}$ The difference in adhesion between the copolymer and

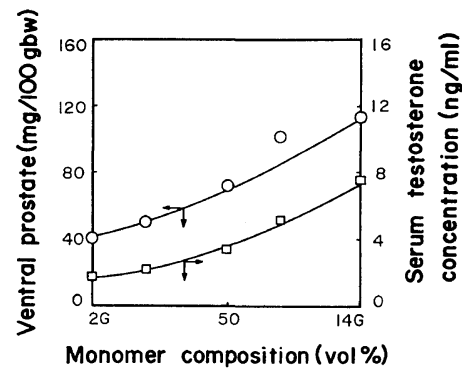

Figure 6. Effects of $2 \mathrm{G} / 14 \mathrm{G}$ carrier composition on physiological response in castrated rats with drugcontaining composites at 30 th day from implantation.

homopolymer is not clear at present. However, it seems reasonable to consider that in the case of a copolymer system, the interaction between the hydrophobic polymer and hydrophilic polymer domains has a significant effect on the adhesion of cells. As in the case of the copolymer of $2 \mathrm{G} / 14 \mathrm{G}$, no cell adhesion occurred in other copolymer systems such as 2G/HEMA, 2G/M9G, and 2G/NVP. Finally, it was found that the apparent total protein adhering to the surface of a testosterone-containing composite is slightly larger than that adhering to the surface of a pure copolymer.

\section{Physiological Response in Rats with Copolymer- Drug Composites}

In the case of castrated rats, though the weight of the ventral prostate should shrink in the absence of testosterone following castration, this weight should be recovered through drug application. The physiological response in castrated rats with testosterone-containing composites was investigated by measuring the weight of the ventral prostate or analyzing the amount of drug in the serum on the 30th day after implantation. The results are shown as a function of $2 \mathrm{G} / 14 \mathrm{G}$ carrier composition in Figure 6. Both the weight of the ventral prostate and serum testosterone concentration increased markedly with increasing $14 \mathrm{G}$ carrier component. The weight of the ventral prostate corresponding to the in vitro rate from the $80 / 20(2 \mathrm{G} / 14 \mathrm{G})$ copolymer composite with relatively low water content, such as $6.8 \%$, was found to be $50.18 \mathrm{mg} / 100 \mathrm{gbw}$ at a release rate of $60 \mu \mathrm{g} / \mathrm{day}$. In contrast, in the 20/80 $(2 \mathrm{G} / 14 \mathrm{G})$ copolymer composite with a relatively high water content such as $22.8 \%$, the weight was found to be $102.28 \mathrm{mg} / 100 \mathrm{gbw}$ at $160 \mu \mathrm{g} /$ day. 
Serum testosterone concentration was found to be 2.21 and $5.34 \mathrm{ng} \mathrm{ml}^{-1}$, in the above order. This indicates that when the in vivo overall apparent

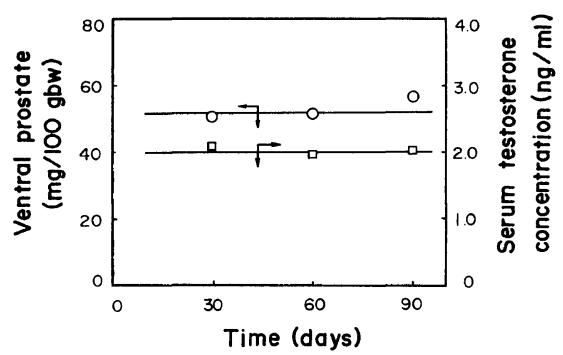

Figure 7. Effects of duration of drug delivery on physiological response in castrated rats with $2 \mathrm{G} / 14 \mathrm{G}$ (80/20) copolymer composite-containing drug.

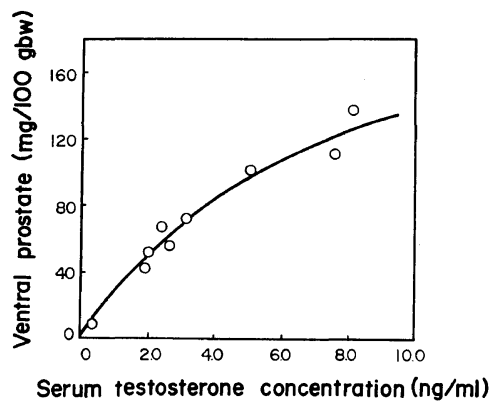

Figure 8. Effects of serum drug concentration on the weight of the ventral prostate in the in vivo drug delivery from various copolymer composites.

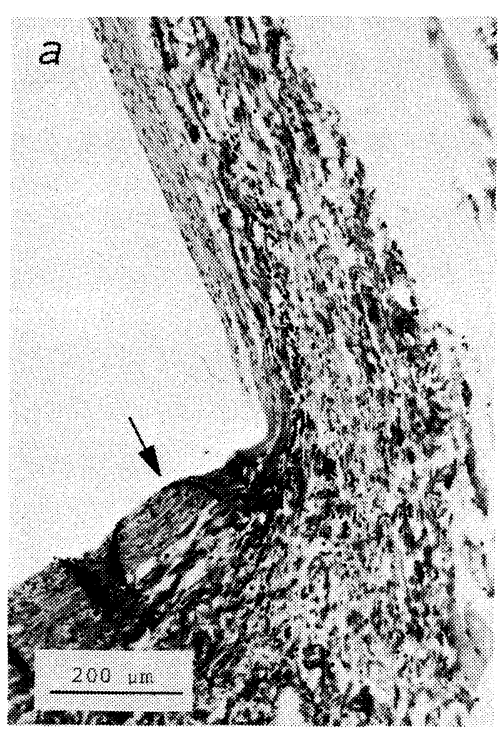

(a) release rate increases by about 3 times, the physiological response increases by about $2-2.5$ times.

The results of physiological response in castrated rats with the 2G/HEMA, 2G/NVP, and 2G/M9G copolymer composites are summarized in Table I. From these results, it is clear that the in vivo efficacy

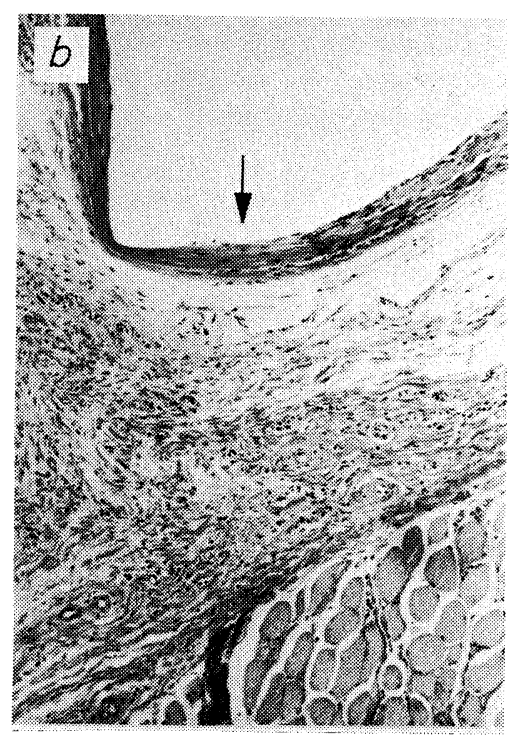

(b)

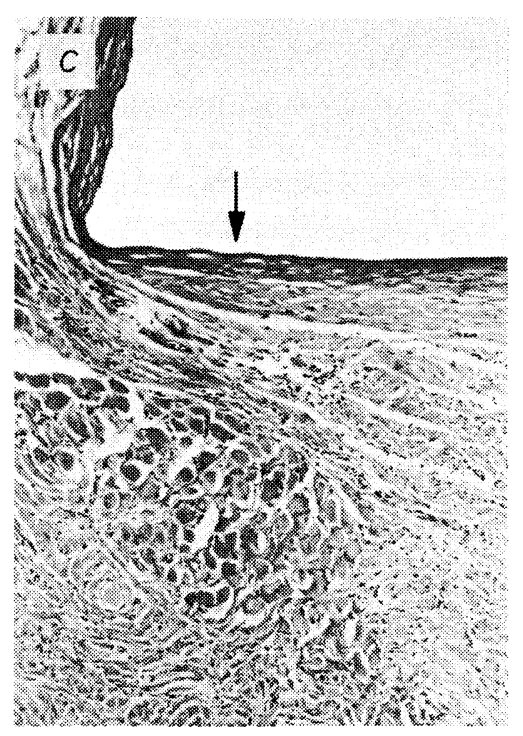

(c)

Figure 9. Photomicrographs of tissues surrounding the pure $2 \mathrm{G} / 14 \mathrm{G}(\mathrm{\gamma} 0 / 20)$ copolymer matrix (stained with hematoxylin and eosin). Implantation time (days): (a), 30; (b), 60; (c), 90. Arrow indicates site of surgical insertion of implant. 
Table II. Pathologic findings from tissues surrounding pure copolymer matrices

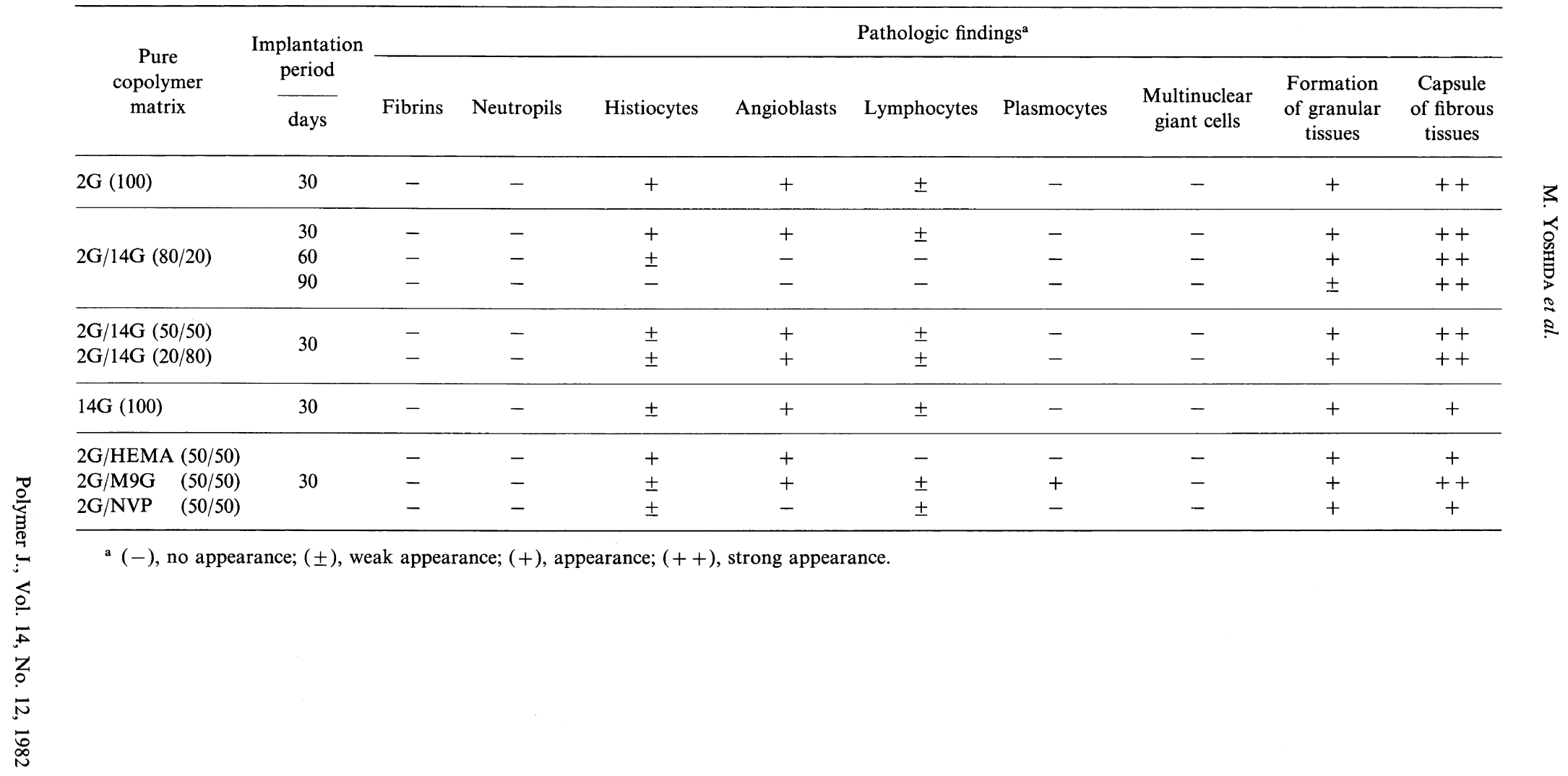


is strongly dependent on the in vitro rate of drug delivery rather than the water content of each copolymer. With increasing the rate, there is a highly siginificant level of physiological response toward the effects of testosterone.

The physiological response in castrated rats over a long period of time was investigated for an 80/20 $(2 \mathrm{G} / 14 \mathrm{G})$ copolymer composite. Figure 7 shows the effects of duration of testosterone delivery on in vivo efficacy with drug-copolymer composites. The in vivo test was carried out over a period of 90 days. Figure 7 shows the durability of considerable efficacy throughout the 90 day test period. This efficacy remained relatively constant throughout the test. In the case of the control rat (only castration), the weight of the ventral prostate and serum testosterone concentration were found to be $8.87 \mathrm{mg} / 100$ gbw and $0.39 \mathrm{ng} \mathrm{ml}^{-1}$, respectively. When $60 \mu \mathrm{g} /$ day of testosterone were given by daily subcutaneous injection to the castrated rats during the 30 day. test period, the weight of the ventral prostate was 13.42 $\mathrm{mg} / 100$ gbw. This shows that the physiological response with drug-copolymer composites is more effective compared to that for the injection tests. This may be attributed to the continued and steady release of testosterone from copolymer composite systems.

Figure 8 shows the effects of serum testosterone concentration on the weight of the ventral prostate in drug delivery from $2 \mathrm{G} /$ other hydrophilic copolymer composite systems. The weight of the ventral prostate increased linearly with increasing quantity of drug in the serum. On the basis of this result, it is quite reasonable to consider that testosterone absorbed gradually from subcutaneous tissues is circulated by blood delivered to the target organ and acts on it effectively.

\section{Biocompatibility of Carrier Copolymers}

We found previously that none of the homopolymers used in this study underwent degradation in vivo. ${ }^{27}$ In order to clarify their reactions toward tissues, the $2 \mathrm{G} /$ other hydrophilic carrier copolymers were implanted subcutaneously in the backs of rats over a long time of period. Figure 9 shows the microphotographs of the tissues stained with hematoxylin and eosin surrounding pure 80/20 (2G/14G) as a function of implantation period. On the 90 day following implantation, it was found that the tissues surrounding the copolymer consisted mainly of capsules of fibrous tissues. Moreover, the pathologic findings of the tissue surrounding other pure copolymers were also investigated by microscopy and are summarized in Table II. From this Table II, it was concluded that the hydrophobic-hydrophilic copolymers as carriers for the drug delivery system have a relatively good biocompatibility.

On the other hand, the foreign body reaction toward certain organs such as the liver and kidney was also evaluated in a similar manner. Four specimens were implanted in each rat. Some organs were found not to be effected by the copolymers.

\section{REFERENCES}

1. F. J. Saunder and A. L. Raymond, U. S. Patent 2,413, 419 (1946).

2. E. D. Draper and C. H. Becker, J. Pharm. Sci., 55, 376 (1966).

3. S. Goto, Igaku no Ayumi, 106, 829 (1978).

4. M. Nakano, K. Takikawa, and T. Arita, Membrane, 3, 141 (1978).

5. J. H. R. Woodland, S. Yolles, D. A. Blake, M. Helrich, and F. J. Meyer, J. Med. Chem., 16, 897 (1973).

6. P. L. Madan, D. K. Madan, and J. C. Price, J. Pharm. Sci., 65, 1476 (1976).

7. S. Kasai and M. Koishi, Chem. Pharm. Bull. (Tokyo), 25, 314 (1977).

8. S. Yolles, T. D. Leafe, J. H. R. Woodland, and F. J. Meyer, J. Pharm. Sci., 64, 348 (1975).

9. T. Kato, R. Nemoto, I. Kumagai, T. Nishimoto, and H. Mori, J. Jpn. Soc. Cancer Ther., 14, 152 (1979).

10. B. Farhadieh, S. Borodkin, and J. D. Buddenhagen, J. Pharm. Sci., 60, 209 (1971).

11. S. K. Chandrasekaran, P. Capozza, and P. S. L. Wong, J. Membrane Sci., 3, 271 (1978).

12. G. M. Zentner, J. R. Cardinai, J. Feijen, and S. Z. Song, J. Pharm. Sci., 68, 970 (1979).

13. H. Hosaka, Y. Murano, H. Tanzawa, Y. Okamura, and H. Kawano, Membrane, 6, 427 (1981).

14. G. D. Colo, V. Carelli, B. Giannaccini, M. F. Serafuni, and F. Bottari, J. Pharm. Sci., 69, 387 (1980).

15. T. J. Roseman and W. I. Higuchi, J. Pharm. Sci., 59, 353 (1970).

16. P. Bass, R. A. Puri, and J. N. Wile, Nature, 208, 591 (1965).

17. Y. W. Chien, S. E. Mares, J. Berg, S. Huber, H. J. Lambert, and K. F. King, J. Pharm. Sci., 64, 1776 (1975).

18. M. Yoshida and I. Kaetsu, J. Appl. Polym. Sci., 26, 687 (1981).

19. M. Yoshida, M. Kumakura, and I. Kaetsu, J. Macromol. Sci. Chem., A14, 555 (1980). 
20. M. Yoshida, M. Kumakura, and I. Kaetsu, Polym. J., 12, 915 (1979).

21. M. Kumakura, M. Yoshida, and I. Kaetsu, Appl. Environmental Microbiol., 37, 310 (1979).

22. M. Kumakura, M. Yoshida, and I. Kaetsu, Eur. J. Appl. Microbiol. Biotechnol., 6, 13 (1978).

23. I. Kaetsu, M. Yoshida, and A. Yamada, J. Biomed. Mater. Res., 14, 185 (1980).

24. I. Kaetsu, M. Yoshida, M. Kumakura, A. Yamada, and Y. Sakurai, Biomaterials, 1, 17 (1980).

25. M. Yoshida, M. Kumakura, and I. Kaetsu, $J$.
Pharm. Sci., 68, 628 (1979).

26. M. Nakamura, T. Takada, T. Takasaki, S. Kobayashi, F. Hanyu, A. Yamada, Y. Sakurai, T. Okawa, I. Kaetsu, and M. Yoshida, Gan to Kagakuryoho, 7, 1824 (1980).

27. M. Yoshida, M. Asano, I. Kaetsu, K. Nakai, H. Yamanaka, T. Suzuki, K. Shida, and K. Suzuki, Biomaterials, to be appear.

28. T. Makino, Folia Endocrinol. Japon., 49, 629 (1973).

29. Y. Imai, A. Watanabe, and E. Masuhara, Trans. Am. Soc. Artif. Intern. Organs, 25, 299 (1979). 